\title{
Microaggregation of hormone-occupied epidermal growth factor receptors on plasma membrane preparations
}

\section{Raphael Zidovetzki ${ }^{1}$, Yosef Yarden ${ }^{2.3}$, Joseph Schlessinger ${ }^{3}$ and Thomas M.Jovin}

\author{
Abteilung Molekulare Biologie, Max-Planck-Institut für Biophysikalische \\ Chemie, Postfach 2841, D-3400 Göttingen, FRG, and ${ }^{3}$ Department of \\ Chemical Immunology, The Weizmann Institute of Science, Rehovot, Israel \\ ${ }^{1}$ Present address: Department of Biology, University of California, \\ Riverside, CA 92521, USA \\ ${ }^{2}$ Present address: Genentech Incorporated, 460 Point San Bruno Boulevard, \\ San Francisco, CA 94080, USA \\ Communicated by T.Jovin
}

The rotational diffusion of the complexes of epidermal growth factor (EGF) with its specific receptor on plasma membrane vesicles prepared from human epidermoid carcinoma A431 cells was studied using the time-resolved polarization of phosphorescence of erythrosin-labeled hormone. The measured rotational correlation times of $16-20 \mu \mathrm{s}$ at $4^{\circ} \mathrm{C}$ are consistent with monomeric freely diffusing EGF receptor. Upon increasing the temperature to $37^{\circ} \mathrm{C}$, the rate of rotational diffusion slows down as evidenced by an increase in the correlation time to $75 \mu \mathrm{s}$. This finding suggests that small clusters of the occupied EGF receptor (microaggregation) form at the higher temperature, a property we have reported previously for occupied receptors on living A431 cells. Subsequent cooling of the membranes leads to a partial reversal of the microaggregation. We conclude that clustering of occupied EGF receptors can proceed at $37^{\circ} \mathrm{C}$ in the absence of metabolic energy and external interactions, e.g. with components of the cytoskeleton, and thus reflects inherent properties of the receptor protein in its natural environment. A lag phase in the time course of microaggregation observed with the isolated membrane preparations may reflect cooperativity in the process of receptor association.

Key words: membrane dynamics/rotational diffusion/phosphorescence/receptor clustering/EGF

\section{Introduction}

Epidermal growth factor (EGF) is a 6045-dalton polypeptide which binds to specific membrane receptors on various epidermal, epithelial, and fibroblastic cells (Carpenter and Cohen, 1979; Adamson and Rees, 1981). Binding triggers a spectrum of biochemical responses in the target cell, such as phosphorylation of membrane proteins and increased uptake of metabolites (Carpenter and Cohen, 1979; Carpenter et al., 1979; Ushiro and Cohen, 1980). The self-phosphorylation of the EGF receptor is due to an inherent tyrosine kinase activity (Cohen et al., 1982; Buhrow et al., 1983). A delayed response is the stimulated proliferation of a number of cell types (Carpenter and Cohen, 1979; Gospodarowicz et al., 1978). The epidermal growth factor receptor (EGF-R) is an integral cell membrane protein present in cells derived from all three germ layers of the embryo (Adamson and Rees, 1981). The wide distribution of this receptor in cells and tissues of mammalian and avian species indicates that EGF may play an important role in growth control. Recent molecular biology studies have revealed the complete nucleotide sequence of the EGF-R precursor and its relationship to viral oncogenes (Ullrich et al., 1984; Downward et al., 1984). The primary amino acid sequence of the receptor has been deduced (Ullrich et al., 1984), and the tentative identification made of an external hormone binding domain, a transmembrane domain and a cytoplasmic domain which includes an ATP binding site and the tyrosine kinase function (Ullrich et al., 1984; Hunter, 1984). Upon binding to cells, EGF induces the rapid formation of microclusters (small aggregates, not distinguishable by light microscopy) (Carpenter and Cohen, 1976; Zidovetzki et al., 1981) which precede the process of internalization mediated by coated pits and other areas of the plasma membrane (Haigler et al., 1979; Gorden et al., 1978). Experiments with anti-EGF receptor monoclonal antibodies have led to the hypothesis that microclustering of receptors may play a role in the early stage of the mitotic signal (Schlessinger et al., 1983). However, other antibodies fail to induce DNA synthesis, suggesting that receptor aggregation is by itself an insufficient stimulus (Gill et al., 1984; Chandler et al., 1985). The phenomenon is probably general within the family of polypeptide hormones. For example, lateral diffusion measurements of nerve growth factor (NGF) bound to its specific receptor indicate the transition from a mobile to an aggregated state (Levi et al., 1980). In the case of insulin, the biological effects of the hormone can be mimicked by cross-linking with antibodies directed against the receptor moiety; a bivalent immunoglobulin is required in order to elicit the effect (Kahn et al., 1978; Jacobs et al., 1978). However, little is known about the mechanism of microclustering or about the requirements for cellular components other than those intrinsic to the plasma membrane, e.g. constituents of the cytoskeletal system and membrane-associated enzymes.

A direct physical approach for studying the mechanism of microaggregation is to measure the rate of receptor movement in the plasma membrane under various conditions. The lateral mobility of the EGF-R has been determined on mouse 3T3 fibroblasts (Schlessinger et al., 1978) and on human epidermoid carcinoma A431 cells (Hillman and Schlessinger, 1982; Rees et al., 1984). The latter are particularly rich in the surface expression of EGF-R ( $2 \times 10^{6} /$ cell; Fabricant et al., 1977). However, lateral diffusion in membranes is not strongly dependent upon the size of the diffusing entity (Saffman, 1976) and will, therefore, not reflect the formation of microclusters consisting of only a few associated receptors. In contrast, the rate of rotational diffusion is very sensitive to the dimensions of the rotating molecule or complex and offers the potential for readily distinguishing between individual isolated receptors and clusters thereof, particularly if experimental conditions can be achieved leading to a transition between the two states.

The analysis of membrane protein rotational diffusion based on time-resolved phosphorescence polarization has proved to be useful in studying the dynamic properties of both in vivo and in vitro systems (Austin et al., 1979; Garland and Moore, 1979; 


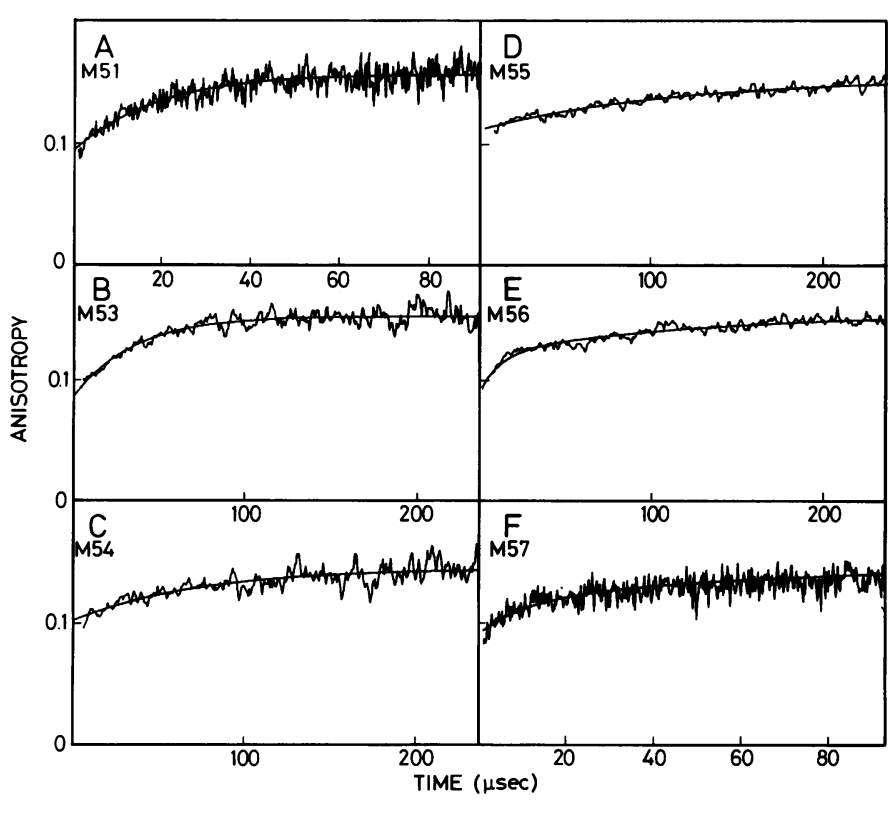

Fig. 1. The decay of phosphorescence anisotropy of Er-EGF-receptor complexes at different temperatures. The smooth lines are the results of the computer fits to the parameters given in Table I. Samples incubated as follows: (A) $40 \mathrm{~min}$ at $4^{\circ} \mathrm{C}$; (B) $45 \mathrm{~min}$ at $4^{\circ} \mathrm{C}$ and $20 \mathrm{~min}$ at $37^{\circ} \mathrm{C}$, measured at $37^{\circ} \mathrm{C}$; (C) $45 \mathrm{~min}$ at $4^{\circ} \mathrm{C}$ and $35 \mathrm{~min}$ at $37^{\circ} \mathrm{C}$, measured at $37^{\circ} \mathrm{C}$; (D) $45 \mathrm{~min}$ at $4^{\circ} \mathrm{C}, 35 \mathrm{~min}$ at $37^{\circ} \mathrm{C}$ and $15 \mathrm{~min}$ at $4^{\circ} \mathrm{C}$, measured at $4^{\circ} \mathrm{C}$; (E) $45 \mathrm{~min}$ at $4^{\circ} \mathrm{C}, 35 \mathrm{~min}$ at $37^{\circ} \mathrm{C}$ and $30 \mathrm{~min}$ at $4^{\circ} \mathrm{C}$, measured at $4^{\circ} \mathrm{C}$; (F) same as (E) but shorter sweep time, demonstrating the presence of short rotational correlation time.

Matayoshi et al., 1983; Garland and Johnson, 1985). The dependence of the rotational diffusion constant on size was exploited in a previous investigation of microclustering and internalization of EGF-receptor complexes on living A431 cells following exposure to $37^{\circ} \mathrm{C}$ (Zidovetzki et al., 1981). In order to clarify the effects of cell metabolism, protein phosphorylation, cytoskeletal interactions and membrane potential on these processes, we undertook similar measurements on EGF-receptor complexes generated with shed membrane vesicles prepared from A431 cells.

\section{Results and Discussion}

We used as a probe the phosphorescent analogue of EGF, erythrosin-EGF, which was shown previously to retain the biological activity of native EGF (Zidovetzki et al., 1981). The phosphorescence anisotropy decay curves at different temperatures of EGF-receptor complexes on membrane vesicles are shown in Figure 1, and the results of fitting these curves to mono- or biexponential decay laws are given in Table I. As in the previous work on living cells (Zidovetzki et al., 1981), a characteristic feature is the decay of the phosphorescence emission anisotropy from an initial value, $r_{\text {in }}$, to a finite limiting anisotropy, $r_{\infty},>0$. This result signifies that the hormone-receptor complex on the membrane vesicles is a relatively rigid structure. Under all conditions studied, the rotational relaxation of $\mathrm{Er}-\mathrm{EGF}$ bound to membrane vesicles had a negative amplitude (i.e. in the direction of increasing anisotropy), as was also the case for whole cells prior to internalization (Zidovetzki et al., 1981). We conclude that the orientation of the probe relative to the rotation axis (and by implication to the hormone and its receptor) is non-random and similar for both whole cells and membranes derived from them by disruption.
Table I. Best fit parameters for the phosphoresence anisotropy decay curves of Er-EGF-receptor complexes on membrane fragments

\begin{tabular}{lrrrrrrrr}
\hline $\begin{array}{l}\text { Incubation conditions } \\
\text { (min) }\end{array}$ & $\begin{array}{l}\mathrm{Temp}^{\mathrm{c}} \\
\left({ }^{\circ} \mathrm{C}\right)\end{array}$ & $\begin{array}{l}\phi_{1} \\
(\mu \mathrm{s})\end{array}$ & $\begin{array}{l}\phi_{2} \\
(\mu \mathrm{s})\end{array}$ & $\alpha_{1}$ & $\alpha_{2}$ & $r_{\infty}$ \\
\cline { 1 - 6 } $4^{\circ} \mathrm{C}$ & $37^{\circ} \mathrm{C}$ & $4^{\circ} \mathrm{C}$ & & & & & & \\
\hline 40 & 0 & 0 & 4 & 19 & & -0.065 & & 0.16 \\
45 & 20 & 0 & 37 & 36 & & -0.067 & & 0.16 \\
45 & 35 & 0 & 37 & & 74 & & -0.044 & 0.15 \\
45 & 35 & 15 & 4 & & 110 & & -0.042 & 0.16 \\
45 & 35 & 30 & 4 & 12 & 120 & -0.029 & -0.034 & 0.16 \\
\hline
\end{tabular}

${ }^{\text {aT }}$ The variation in values obtained from repeated records of given samples was $<15 \%$ for $\phi$ and $\alpha$ (in mono-exponential decays) and for $r_{\infty}$

${ }^{\text {b }}$ The samples were incubated and measured first at $4^{\circ} \mathrm{C}$, then at $37^{\circ} \mathrm{C}$ and finally at $4^{\circ} \mathrm{C}$ with the indicated timing.

'Temperature during the measurement.

The phosphorescence anisotropy was significantly higher for the membrane vesicles $\left(r_{\text {in }}=0.09, r_{\infty}=0.13\right)$ than for whole cells $\left(r_{\text {in }}=0.04, r_{\infty}=0.08\right.$; Zidovetzki et al., 1981). This feature reflects the greater optical clarity of the membrane suspensions (see Materials and methods) but may also be indicative of a decrease in local probe and protein segmental motions which ordinarily lead to an initial unresolved depolarization in the submicrosecond range. (For technical reasons, we were unable to perform measurements at times shorter than a few $\mu \mathrm{s}$.) Since the amplitude of the observed anisotropy decay was unchanged, the parameter $r_{\text {in }} / r_{\infty}$-which is a measure of orientational constraint of the probe at equilibrium (Kinosita et al., 1977, 1984)increased from the value of 0.5 for whole cells to 0.7 for the membrane vesicles. This finding suggests that the equilibrium (re)orientation of the rotation axis, i.e. of the EGF receptors, is somewhat more restricted on membrane vesicles, a distinction which may result from the more dynamic nature of plasma membranes in living cells in which the metabolically-driven processes of remodelling and turnover are operative.

At $4^{\circ} \mathrm{C}$, the rotational correlation time $(\phi)$ of EGF-receptor complexes was 16-20 $\mu \mathrm{s}$, compared with 25-50 $\mu \mathrm{s}$ for living cells (Zidovetzki et al., 1981). Prolonged incubation (1 h) of the vesicles with EGF at $4^{\circ} \mathrm{C}$ did not lead to a change in the rotational correlation time. A similar treatment of living cells resulted in the increase of $\phi$ to $95 \mu \mathrm{s}$ (Zidovetzki et al., 1981). The observation that the rotational mobility at $4^{\circ} \mathrm{C}$ of Er-EGF-receptor complexes on plasma vesicles is similar to that of complexes on whole cells after short incubation times is consistent with a molecular structure consisting of single hormone-receptor complexes and/or of small microclusters (2-3 receptors). The similarity of the $\phi$ values between living cells and membrane vesicles indicates that, under the conditions examined, structures other than those inherent to the plasma membrane do not significantly affect the rotational mobility of the Er-EGF-receptor complexes.

The increase in temperature led to a gradual lengthening of the rotational correlation times to a value of $74 \mu$ s (Figure 1), i.e. the same phenomenon seen with living cells albeit to a lesser degree. As the increase in temperature and 'fluidity' of the membrane should cause a decrease in the rotational correlation time, we attribute the observed slowing of the rotation, as in the previous report (Zidovetzki et al., 1981), to the microclustering of the EGF-receptor complexes. The fact that this property is observed with membrane vesicles shows that the ability to aggregate is an intrinsic property of the EGF-R and that the cell 
membrane alone supplies the environment required for the facilitation of the process at $37^{\circ} \mathrm{C}$.

The longer incubation of the vesicles $(>1 \mathrm{~h})$ at $37^{\circ} \mathrm{C}$ did not result in a further increase in values of $\phi$. Thus, although microclustering does occur on the membrane vesicles, the size of the aggregates is probably smaller than on the living cells. Alternatively, it is possible that additional constraints are imposed by intact coated pits or other membrane structure(s) with which the occupied receptor probably interacts. The system was investigated further by fast cooling of the sample back to $4^{\circ} \mathrm{C}$ after incubation and measurement at $37^{\circ} \mathrm{C}$ (Figure 1D). After a short time at $4^{\circ} \mathrm{C}$ (15 $\mathrm{min})$, the rotational correlation time actually increased, in accordance with the expected instantaneous effect of temperature on the apparent fluidity of the membrane. However, after extended incubation at $4^{\circ} \mathrm{C}(40 \mathrm{~min})$, the second, faster component (shorter rotational correlation time) reappeared (Figure 1E). The fitting of the curve in Figure $1 \mathrm{E}$ to a bi-exponential decay law yielded two correlation times, $\phi_{1}=12 \mu \mathrm{s}$ and $\phi_{2}=120 \mu \mathrm{s}$, with $54 \%$ of the amplitude contributed by the slower relaxation (Table I). An overnight incubation of the sample at $4{ }^{\circ} \mathrm{C}$ led to a further decrease of $\phi_{2}$ to the value of $57 \mu \mathrm{s}$. Thus, microclustering of the EGF-receptor complexes is partially reversible, with about half of the receptors dissociating into monomers or very small clusters (2-3 molecules). Although the rotational mobility of such a system was satisfactorily analyzable in terms of two components, we cannot rule out the presence of aggregates of intermediate size.

The partial reversibility of the aggregation exhibited by occupied receptors argues against the possibility that they would cluster in the absence of EGF, that is, solely as an effect of elevated temperature. In such a case, incubating the membranes at $37^{\circ} \mathrm{C}$ without EGF, and subsequent cooling of the sample and incubation with EGF should result in the bi-exponential rotational depolarization pattern shown in Figure 1E. However, we observed in such an experiment a mono-exponential decay, indistinguishable from that of membrane vesicles which were not pre-warmed to $37^{\circ} \mathrm{C}$. It follows that the binding of EGF is a prerequisite for stable aggregation of the receptor. Such a property is consistent with a temperature-dependent conformational change coupled to the binding of EGF to the receptor and affecting the equilibrium degree of homologous association.

We determined the time dependence of the microaggregation process at $37^{\circ} \mathrm{C}$. After initial measurements at $4^{\circ} \mathrm{C}$, cells were warmed to $37^{\circ} \mathrm{C}$ and the measurements of rotational diffusion performed in rapid succession. A significant feature of the progress curve was a delay of $\sim 25$ min before the characteristic increase in the rotational correlation time. (The results of one such experiment are presented in graphical form elsewhere: Figure 2 in Matayoshi et al., 1983.) This lag phase is indicative of cooperativity in at least one of the steps leading to clustering. The most obvious candidates would be the postulated initial conformational change in the EGF-receptor complex and the association reaction itself. A conformational change involving individual EGF-R molecules would be expected to occur relatively rapidly. It is more likely that the observed lag is attributable to the cooperative process by which hormone-occupied EGF receptors encounter each other and establish rigid contacts.

In summary, the results presented in this paper indicate that a $37^{\circ} \mathrm{C}$ EGF induces the aggregation of receptors in membrane fragments prepared from A431 cells. Subsequent cooling leads to a partial reversal of receptor microaggregation. We conclude that the microclustering of occupied EGF receptor at $37^{\circ} \mathrm{C}$ which occurs in cell-free systems reflects an intrinsic property of the receptor.

\section{Materials and methods}

\section{Reagents}

EGF was purified from male mouse submaxillary glands as described (Savage and Cohen, 1972). EGF was labelled at the $\alpha$ amino group with erythrosin-5'isothiocyanate (the gift of Dr P.Garland) according to Schechter et al. (1978). The phosphorescence measurements were done in phosphate-buffered saline (PBS): $137 \mathrm{mM} \mathrm{NaCl}, 2.7 \mathrm{mM} \mathrm{KCl}, 7.9 \mathrm{mM} \mathrm{Na}_{2} \mathrm{HPO}_{4}, 1.5 \mathrm{mM} \mathrm{KH}_{2} \mathrm{PO}_{4}, 0.87 \mathrm{mM}$ $\mathrm{CaCl}_{2}, 0.5 \mathrm{mM} \mathrm{MgCl}$, pH 7.2.

Cells and culture

Human epidermoid carcinoma cells, A431 (Fabricant et al., 1977), were grown in Dulbecco's modified Eagle's medium supplemented with $10 \%$ fetal calf serum in $10 \% \mathrm{CO}_{2}$.

\section{Membrane preparations}

Plasma membrane vesicles were prepared from A431 cells according to Thom et al. (1977). The procedure produces large membrane vesicles sedimentable at $12000 \mathrm{~g}$, the rotational relaxation of which should lie in a much longer time range than that explored in our experiments. The concentration of proteins in the stock suspensions of plasma vesicles was determined using the method of Lowry $e t$ al. (1951), and was typically of the order of $6-7 \mu \mathrm{g} / \mu \mathrm{l}$ of membrane suspension. The EGF binding capacity of the membrane preparations was determined as described (Schreiber et al., 1981); a suspension containing $10 \mu \mathrm{g}$ of membrane protein was equivalent to $10^{5} \mathrm{~A} 431$ cells.

\section{Preparation of membrane samples for phosphorescence measurements}

In general, the aliquots of stock membrane suspensions with the total protein content of $\sim 300 \mu \mathrm{g}$ were incubated with $15 \mathrm{pmol}$ of $\mathrm{Er}-\mathrm{EGF}$ for $10 \mathrm{~min}$ at $4^{\circ} \mathrm{C}$. The membranes were then washed twice with cold PBS and resuspended in the volume of $300 \mu \mathrm{l}$ of cold PBS for the measurements. The samples were purged of dissolved $\mathrm{O}_{2}$ by a continuous argon flow into the cuvettes and gentle agitation with a Teflon plunger.

\section{Measurements of rotational diffusion}

The delayed luminescence spectrometer used for time-resolved measurements of polarized phosphorescence is described elsewhere (Matayoshi et al., 1983). The measurements and the analysis of the data were performed as described in our previous work (Zidovetzki et al., 1981). Excitation of the samples was at $515 \mathrm{~nm}$, and individual records were collected at a frequency of $10-20 \mathrm{~Hz}$ and averaged. The membrane preparations presented far fewer problems with light scattering than living cells (Zidovetzki et al., 1981) and we were able to work at a higher concentration of the probe. Consequently, 1024 records sufficed to obtain good records. The data were collected as parallel $\left(I_{1}\right)$ and perpendicular $\left(I_{t}\right)$ polarized emission components, and the total phosphorescence emission calculated as $S(t)$ $=\mathrm{I}_{1}+2 \mathrm{I}{ }_{\perp} . \mathrm{I}_{\perp}$ was corrected for the inequality of the gain of the photomultipliers and the finite aperture of the optics monitoring the emission. The emission anisotropy was calculated as $r(t)=\left(\mathrm{I}_{1}-\mathrm{I}_{\perp}\right) / S(t)$. The decay of the emission anisotropy $r(t)$ is a measure of the rate of the rotational relaxation of the phosphorescent probe bound to a macromolecule, and can be represented as a sum of exponential terms in the form $r(t)=\sum \alpha_{i} \exp \left(-t / \phi_{i}\right)+r_{\infty}$, where the time constants, $\phi_{i}$ (rotational correlation times), depend on the rotational diffusion constants reflecting the segmental, wobbling, and global motions of the macromolecule and probe and the coefficients $\alpha_{\mathrm{i}}$ are the respective amplitudes. The constant limiting anisotropy, $r_{\infty}$, depends on the degree of orientational constraints on the movements of the rotational axis of a molecule. The initial anisotropy $r_{\text {in }}=$ $\Sigma \alpha_{i}+r_{\infty}$. For a more complete description of the formalism used see Cherry (1978), Lipari and Szabo (1980) and Zidovetzki et al. (1981).

\section{Acknowledgements}

This work was supported by the Max Planck Society, the National Institutes of Health (grant CA-25820 to J.S.) and the European Molecular Biology Organization (short-term fellowship to Y.Y.).

\section{References}

Adamson,E.D. and Rees,A.R. (1981) Mol. Cell. Biochem., 34, 129-152. Austin,R.H., Chan,S.S. and Jovin,T.M. (1979) Proc. Natl. Acad. Sci. USA, 76, 5650-5654.

Buhrow,S.W., Cohen,S., Garbers,D.L. and Steros,J.V. (1983) J. Biol. Chem., 258, 7824-7827.

Carpenter,G. and Cohen,S. (1976) J. Cell Physiol., 88, 227-238.

Carpenter,G. and Cohen,S. (1979) Ann. Rev. Biochem., 48, 193-216.

Carpenter,G., King,L.J. and Cohen,S. (1979) Nature, 276, 409-410. 
Chandler,L.P., Chandler,C.E., Hosang,M. and Shooter,E.M. (1985) J. Biol. Chem., 260, 3360-3367.

Cherry,R.J. (1978) Methods Enyzmol., 54, 47-61.

Cohen,S., Ushiro,H., Stoscheck,C. and Chinkers,M. (1982) J. Biol. Chem., 257, 1523-1531.

Downward,J., Yarden,Y., Mayes,E., Scrace,G., Totty,N., Stockwell,P., Ullrich, A., Schlessinger,J. and Waterfield,M.D. (1984) Nature, 307, 521-527.

Fabricant,R.N., De Larco,J.E. and Todaro,G.J. (1977) Proc. Natl. Acad. Sci. USA, 74, 565-569.

Garland,P.B. and Moore,C.H. (1979) Biochem. J., 113, 561-572.

Garland,P.B. and Johnson,P. (1985) In Bayley,P.M. and Dale,R.E. (eds), Spectroscopy and the Dynamics of Molecular Biological Systems. Academic Press, New York, pp. 95-118.

Gill,G.N., Kawamoto,T., Cochet,C., Le,A., Sato,D.J., Masui,H., McLeod,C. and Mendelsohn,J. (1984) J. Biol. Chem., 219, 7755-7760.

Gorden,P., Carpentier,J., Cohen,S. and Orci,L. (1978) Proc. Natl. Acad. Sci. USA, 75, 5025-5029.

Gospodarowicz,D., Greenburg,G., Bialecki,H. and Zetter,B.R. (1978) In Vitro, 14, 85-118.

Haigler,H.T., McKanna,J.A. and Cohen,S. (1979) J. Cell Biol., 81, 382-395.

Hillman,G.M. and Schlessinger,J. (1982) Biochemistry, 21, 1667-1672.

Hunter,T. (1984) Nature, 311, 414-416.

Jacobs,S., Chang,K.-J. and Cuatrecasas,P. (1978) Science, 200, 1283-1284.

Jovin,T.M. (1984) Mol. Immunol., 21, 1147-1149.

Kahn,C.R., Baird,K.L., Jarrett,D.B. and Flier,J.S. (1978) Proc. Natl. Acad. Sci. USA, 75, 4209-4213.

Kinosita,Jr,K., Kawato,S. and Ikegami,A. (1977) Biophys. J., 20, 289-305.

Kinosita,Jr,K., Kawato,S. and Ikegami,A. (1984) Adv. Biophys., 17, 147-203.

Levi,A., Shechter,Y., Neufeld,E. and Schlessinger,J. (1980) Proc. Natl. Acad. Sci. USA, 77, 3469-3473.

Lipari,T. and Szabo,A. (1980) Biophys. J., 30, 489-506.

Lowry,O.H., Rosebrough,N.J., Farr,A.L. and Randall,R.J. (1951) J. Biol. Chem., 193, 265-275.

Matayoshi,E.D., Corin,A.F., Zidovetzki,R., Sawyer,W.N. and Jovin,T.M. (1983) In Sund,H. and Veeger,C. (eds), Mobility and Recognition in Cell Biology. Walter de Gruyter, Berlin, pp. 119-134.

Rees,H.R., Gregoriou,M., Johnson,P. and Garland,P.B. (1984) EMBO J., 3, $1843-1847$.

Saffman,P.G. (1976) J. Fluid Mech., 73, 593-602.

Savage,C.R. and Cohen,S. (1972) J. Biol. Chem., 247, 7609-7611.

Schechter,Y., Schlessinger,J., Jacobs,S., Change,K.J. and Cuatrecasas,P. (1978) Proc. Natl. Acad. Sci. USA, 75, 2135-2139.

Schlessinger,J., Schechter,Y., Cuatrecasas,P., Willingham,M.C. and Pastan,I. (1978) Proc. Natl. Acad. Sci. USA, 75, 5353-5357.

Schlessinger,J., Schreiber,A.B., Levi,A., Lax,I., Libermann,T. and Yarden,Y. (1983) CRC Crit. Rev. Biochem., 14, 93-111.

Schreiber,A.B., Yarden,Y. and Schlessinger,J. (1981) Biochem. Biophys. Res. Commun., 101, 517-523.

Thom,D., Powell,A.J., Lloyd,C.W. and Rees,D.A. (1977) Biochem. J., 168, 187-194.

Ullrich,A., Coussens,L., Hayflick,J.S., Dull,T.J., Gray,A., Tam,A.W., Lee,J., Yarden,Y., Libermann,T.A., Schlessinger,J., Downward,J., Mayes,E.L.V., Whittle,N., Waterfield,M.D. and Seeburg,D.M. (1984) Nature, 309, 418-425. Ushiro,H. and Cohen,S. (1980) J. Biol. Chem., 255, 8363-8365.

Zidovetzki,R., Yarden,Y., Schlessinger,J. and Jovin,T. (1981) Proc. Natl. Acad. Sci. USA, 78, 1337-1341.

Received on 17 October 1985; revised on 12 December 1985 